Vol. 14, $n^{\circ} 1 \mid 2010$

Varia

\title{
Galeotti (Mark), Organised Crime in History
}

London, New York, Routledge, 2008, 190 pp., ISBN 9780415478175.

\section{Clive Emsley}

\section{(2) OpenEdition}

\section{Journals}

Electronic version

URL: https://journals.openedition.org/chs/1170

DOI: $10.4000 /$ chs. 1170

ISSN: 1663-4837

\section{Publisher}

Librairie Droz

\section{Printed version}

Date of publication: 1 May 2010

Number of pages: 118-119

ISBN: 978-2-600-01425-0

ISSN: 1422-0857

\section{Electronic reference}

Clive Emsley, "Galeotti (Mark), Organised Crime in History", Crime, Histoire \& Sociétés / Crime, History \& Societies [Online], Vol. 14, $n^{\circ} 1$ | 2010, Online since 07 June 2010, connection on 24 March 2022. URL: http://journals.openedition.org/chs/1170 ; DOI: https://doi.org/10.4000/chs.1170 
que de leurs intérêts professionnels ${ }^{8}$. Les analyses socio-historiques s'enrichiraient à élargir l'investigation aux pratiques et dans le cas précis de l'étude de Serge Defois aux pratiques de défenses ou de conseils judiciaires, comme il le propose dans sa courte partie sur l'activité de défense durant la période d'occupation de 1940 à 1944 . Par exemple, la démarche visant à produire une description, par ailleurs implicitement normative, de l'évolution du barreau nantais en terme de «dynamisme» ou de «repli» pourrait se compléter par une mesure de l'«efficacité» professionnelle des avocats. Les procès gagnés, la recherche de sources attestant d'une satisfaction des justiciables ou celles indiquant un sentiment de justice qu'aurait généré chez les parties le travail de conseil seraient des outils également pertinents et novateurs pour appréhender le «rayonnement» du barreau à partir d'éléments exogènes.

Françoise Briegel

Université de Genève, Visiting scholar, Center for the Study of Law and Society, Berkeley University Francoise.Briegel@unige.ch

\section{Galeotti (Mark), Organised Crime in History, London, New York, Routledge, 2008, 190 pp., ISBN 9780415478175.}

The popular press is full of stories about the threat from organised crime - from the Mafia (the word that has become synonymous with organised crime), from the Russian Mafia, Columbian drugs cartels, Chinese Triads, Japanese Yakuza, Jamaican Yardies and so on. Criminal justice professionals co-operate and collaborate against it; politicians proclaim it a major threat and indeed in 2003 the United Nations ratified a Convention on Transnational Organised Crime. It is declared to be a modern phenomenon. Even respectable criminologists in the United States situated its origins back no further than the southern European immigrants, especially Italians and above all Sicilians, who crossed the Atlantic in the late nineteenth and early twentieth centuries brining their own, often violent systems of entrepreneurship.

In this collection Mark Galeotti and the authors that he has assembled set out to challenge the accepted wisdom. In his introduction Galeotti suggests, as a working definition: 'Organised crime is a continuing enterprise, apart from traditional and legal social structures, within which a number of persons work together under their own hierarchy to gain power and profit for their private gain, through illegal activities' (p. 6). The idea that such crime is always 'apart from traditional and legal social structures' might be debated as tending to exclude some corporate duplicity and systemic offences by functionaries of the state, sometimes with the state's blessing. Nevertheless the argument that underpins the collection, that any state or social structure can be the setting for continuing criminal enterprise with the perpetrators working within their own hierarchies, is well made. Generally speaking the essays support the case, though Wisam Mansour's jeu d'esprit on the tale of Ali Baba and the 40 thieves as an allusion to crime in medieval Baghdad is pushing the limits. So too is Frances Berdan's study of crime in pre-conquest Mexico, which asserts that the Aztec

Simona Cerruti, «La construction des catégories sociales », in Jean Boutier, Dominique Julia (eds), Passés recomposés, Champs et Chantiers de l'Histoire, Paris, Éd. Autrement, 1995, pp. 224-242. 
system was too short-lived for any serious organised crime to develop. Kelly Hignett and Arne Bialuschewski are on safer ground with their respective studies of border peoples in Central and Easter Europe in the early modern period and the pirates of the late seventeenth and early eighteenth-century Atlantic world. In both instances, at least at some point in their history, the people involved were sanctioned by states. In the former instance as the protectors of porous, ill-defined frontiers; in the latter as privateers organised to prey on the merchant marine of others. Paul Sanders's essay on the semi-official involvement of Nazi functionaries in the Black Markets of occupied powers provides fascinating twentieth-century resonances.

American assumptions about the origins of organised crime are confronted head on by Jane Dickson-Gilmore and Michael Woodiwiss. They describe the way in which the narrative emerged from the bigotry and concerns about new immigrants shared by established white Americans. They also focus on some of the systematic, organised offending by the seventeenth- and eighteenth-century ancestors of those white Americans. While contemporary American movies contribute to world-wide beliefs about organised crime, it is worth remembering that one of the greatest ever thrillers of the cinema - Fritz Lang's $M$ - featured the Ringvereine. Lang allegedly had dealings with the Ringvereine while making his film. A large number of police officers, businessmen and other highly respectable individuals also had dealings with this association that appears to have enjoyed its heyday in Weimar Germany. Arthur Hartmann and Klaus von Lampe bring together most of what is known about the Ringvereine, though quite how much crime its members committed once bound into the association, remains a mystery.

The two remaining essays are by Galeotti himself and Nadia Gerspacher. Galeotti picks up on some of Hignett's work sketching a long tradition of organised criminality in Russia and suggesting that the contemporary Russian Mafia is not that new but can be seen in some ways as emerging from organised criminals in the Soviet gulags. Gerspacher offers a speedy journey through police co-operation from the worries about mid-nineteenth-century revolutionaries, through turn of the century anxieties over anarchists and white slavers, to the modern war against transnational crime and terror.

As with most collections of this sort the intention here was ambitious. Also, as with most collections, there are some essays here that seem more focused on the topic, and that offer more insight than others. It is unlikely to overturn the popular narrative, but then few serious history books ever do.

\author{
Clive Emsley \\ The Open University (Milton Keynes) \\ c.emsley@open.ac.uk
}

\title{
McRorie Higgins (Peter), Punish or Treat? Medical care in english prisons (1770-1850), Oxford, Trafford Publishing, 2007, 283 pp., ISBN 142510153 4, 32 illustrations in texte.
}

En 1978, dans A just measure of pain: the penitentiary in the industrial revolution 1750-1850 (Londres, MacMillan Press), Michael Ignatieff impute la culture carcérale triomphante dans le seconde partie du siècle des Lumières aux idéaux réformistes, rédempteurs, disciplinaires et correctifs du philanthropisme et du 